\title{
Optimization of Osmotic Dehydration Process of Pineapple by Response Surface Methodology
}

\section{Sridevi M and Genitha Er TR*}

Department of Food Process Engineering, Sam Higginbottom Institute of Agriculture, Technology and Sciences India

\begin{abstract}
Response Surface Methodology was used for quantitative investigation of water loss, solid gain \& weight reduction during osmotic dehydration of pineapple in sugar syrup. Effects of temperature $\left(30,35,40,45 \& 50^{\circ} \mathrm{C}\right)$, processing time $(30,60,90,120 \& 150 \mathrm{~min})$, sugar concentration $\left(40,45,50,55 \& 60^{\circ} \mathrm{B}\right)$ and sample to solution ratio $1: 10$ (constant) on osmotic dehydration of pineapple were estimated. Quadratic regression equations describing the effects of these factors on the water loss, solid gain \& weight reduction were developed. It was found that effects of temperature and sugar concentrations were more significant on the water loss than processing time. For solid gain, processing time \& sugar concentration were the most significant factors. The osmotic dehydration process was optimized for water loss, solid gain \& weight reduction. The optimum conditions were found to be temperature $38.2^{\circ} \mathrm{C}$, processing time $128.7 \mathrm{~min}$ and sugar concentration $44.05^{\circ} \mathrm{B}$. At these optimum values, water loss, solid gain \& weight reduction were found to be $30.0921 \%, 13.3634 \% \& 20.3772 \%$ respectively.
\end{abstract}

Keywords: Optimization; Osmotic dehydration; Pineapple; Sugar solution; Response surface methodology

\section{Introduction}

In most tropical developing countries, the natural abundance of tropical fresh fruits often leads to a surplus with regard to the local requirements. Unfortunately, the excess of these fruits is not always fully used, once a limited variety and quantity of tropical fruit products are produced and commercialized.

The relatively short shelf life of fresh fruit after harvest is one of the main factors that demonstrate the necessity of developing an efficient and cheap preservation process. Also, the growing search for products with similar sensory and nutritional properties to fresh fruits, such as minimally processed fruits and vegetables, and for products enriched with some compounds, such as functional foods, also stimulates the food industry to look for new food preservation techniques.

One of the techniques being widely studied is osmotic dehydration. The process involves removal of water by immersing them in concentrated aqueous solutions mainly sugar, salt and spices. In osmotic dehydration, three types of counter-current mass transfer occur: (i) water flows from the product to the solution, (ii) a solute transfer from solution to the product and (iii) a leaching out of the product's own solutes (sugars, organic acids, minerals, vitamins, etc.) [1-3].

Besides reducing the drying time, osmotic dehydration is used to treat fresh produce before further processing to improve sensory, functional and even nutritional properties. It has been proven to improve the texture characteristics of thawed fruits and vegetables $[4,5]$, decreases structural collapse [6,7], and retain natural colour as well as volatile compounds during subsequent drying [8]. Water content reduction and sugar gain during osmotic dehydration have been observed to have some cryoprotectant effects on colour and texture in several frozen fruits [4].The two most important advantages for its use as pretreatment in a complementary process are: quality improvement and energy saving [1].

Response surface methodology (RSM) is widely used in food industries. In RSM, several factors are simultaneously varied. The multivariate approach reduces the number of experiments, improves statistical interpretation possibilities, and evaluates the relative significance of several affecting factors even in the presence of complex interactions. It is employed for multiple regression analysis using quantitative data obtained from properly designed experiments to solve multivariate equations simultaneously.

The objectives of this study are to study the effects of sugar concentration, temperature and processing time over the weight reduction, water loss and solid gain in the osmotic dehydration of pine apple and to determine the optimum operating conditions (Temperature, Immersion Time, Sugar Concentration) that maximizes water loss and weight reduction and minimizes the solid gain by response surface methodology.

\section{Materials and Methods}

\section{Raw materials}

Fresh, good quality Kew variety Pineapple (ripe) were procured from the local market Allahabad on daily basis prior to each set of experiment.

\section{Experimental design and statistical analysis}

Response surface methodology (RSM) was used to estimate the main effects of osmotic dehydration process on water loss (WL) and Solid gain (SG) in pineapple. A central composite design was used in temperature $\left(30,35,40,45 \& 50^{\circ} \mathrm{C}\right)$, processing time $(30,60,90,120$

*Corresponding author: Genitha Er TR, Department of Food Process Engineering, Sam Higginbottom Institute of Agriculture, Technology and Sciences (SHIATS), Allahabad - 211007, UP, India, E-mail: genithaimmanuel@yahoo.co.in

Received May 22, 2012; Accepted July 24, 2012; Published July 28, 2012

Citation: Sridevi M, Genitha Er TR (2012) Optimization of Osmotic Dehydration Process of Pineapple by Response Surface Methodology. J Food Process Technol 3:173. doi:10.4172/2157-7110.1000173

Copyright: ( 2012 Sridevi M, et al. This is an open-access article distributed under the terms of the Creative Commons Attribution License, which permits unrestricted use, distribution, and reproduction in any medium, provided the original author and source are credited. 
Citation: Sridevi M, Genitha Er TR (2012) Optimization of Osmotic Dehydration Process of Pineapple by Response Surface Methodology. J Food Process Technol 3:173. doi:10.4172/2157-7110.1000173

Page 2 of 7

\& $150 \mathrm{~min})$, sugar concentration $\left(40,45,50,55 \& 60^{\circ} \mathrm{B}\right) \&$ sample to solution ratio kept constant (1:10) being the independent variables Table 1. For the generated 30 experiments, RSM was applied to the experimental data using design expert 6.0.10.

\section{Osmotic dehydration process}

The pineapple was peeled and cut into $15 \mathrm{~mm}^{3}$ cubes. The prepared samples were subjected to osmotic dehydration according to the experimental design shown in Table 2. The temperature was controlled using a constant temperature water bath. The ratio of sample to solution was maintained at 1:10 in order to ensure concentration of the osmotic solution did not change significantly during the experiment. The samples were withdrawn, rinsed quickly in water, blotted gently with a tissue paper in order to remove adhering water and then dried in a tray drier at $70^{\circ} \mathrm{C}$ for $18 \mathrm{~h}$. In each of the experiment fresh osmotic syrup was used.

\section{Experimental design for optimization of osmotic dehydration of pineapple}

Response Surface Methodology was applied to the experimental

\begin{tabular}{|c|c|c|c|c|c|c|}
\hline \multirow[b]{2}{*}{ Symbol } & \multirow[b]{2}{*}{ Independent Variables } & \multicolumn{5}{|c|}{ Range and levels } \\
\hline & & -2 & -1 & 0 & +1 & +2 \\
\hline $\mathrm{x}_{1}$ & Temperature ${ }^{\circ} \mathrm{C}$ & 30 & 35 & 40 & 45 & 50 \\
\hline$x_{2}$ & Immersion time (min) & 30 & 60 & 90 & 120 & 150 \\
\hline $\mathrm{X}_{3}$ & Sugar concentration ${ }^{\circ} \mathrm{B}$ & 40 & 45 & 50 & 55 & 60 \\
\hline
\end{tabular}

$X 1=\frac{\text { temperature }-40}{5}$

..(1) $X 2=\frac{\text { immersiontime }-90}{30}$

...(2) $X 3=\frac{\text { sugar concentration }-50}{5}$.

Table 1: Process variables and their levels of experimental design.

\begin{tabular}{|c|c|c|c|c|c|c|}
\hline \multirow[b]{2}{*}{ Design } & \multicolumn{3}{|c|}{ Actual Values } & \multicolumn{3}{|c|}{ Coded values } \\
\hline & $X_{1}$ & $X_{2}$ & $\mathbf{X}_{3}$ & $x_{1}$ & $x_{2}$ & $\mathbf{X}_{3}$ \\
\hline 1 & 40 & 90 & 50 & 0 & 0 & 0 \\
\hline 2 & 45 & 60 & 45 & 1 & -1 & -1 \\
\hline 3 & 35 & 60 & 55 & -1 & -1 & 1 \\
\hline 4 & 40 & 90 & 50 & 0 & 0 & 0 \\
\hline 5 & 45 & 60 & 45 & 1 & -1 & -1 \\
\hline 6 & 40 & 90 & 60 & 0 & 0 & 2 \\
\hline 7 & 45 & 60 & 55 & 1 & -1 & 1 \\
\hline 8 & 35 & 120 & 45 & -1 & 1 & -1 \\
\hline 9 & 50 & 90 & 50 & 2 & 0 & 0 \\
\hline 10 & 45 & 120 & 45 & 1 & 1 & -1 \\
\hline 11 & 40 & 90 & 40 & 0 & 0 & -2 \\
\hline 12 & 30 & 90 & 50 & -2 & 0 & 0 \\
\hline 13 & 40 & 150 & 50 & 0 & 2 & 0 \\
\hline 14 & 35 & 120 & 55 & -1 & 1 & 1 \\
\hline 15 & 40 & 90 & 60 & 0 & 0 & 2 \\
\hline 16 & 35 & 60 & 45 & -1 & -1 & -1 \\
\hline 17 & 45 & 120 & 55 & 1 & 1 & 1 \\
\hline 18 & 35 & 120 & 45 & -1 & 1 & -1 \\
\hline 19 & 40 & 90 & 40 & 0 & 0 & -2 \\
\hline 20 & 45 & 120 & 45 & 1 & 1 & -1 \\
\hline 21 & 40 & 30 & 50 & 0 & -2 & 0 \\
\hline 22 & 35 & 60 & 45 & -1 & -1 & -1 \\
\hline 23 & 40 & 30 & 50 & 0 & -2 & 0 \\
\hline 24 & 35 & 60 & 55 & -1 & -1 & 1 \\
\hline 25 & 35 & 120 & 55 & -1 & 1 & 1 \\
\hline 26 & 40 & 150 & 50 & 0 & 2 & 0 \\
\hline 27 & 45 & 60 & 55 & 1 & -1 & 1 \\
\hline 28 & 45 & 120 & 55 & 1 & 1 & 1 \\
\hline 29 & 50 & 90 & 50 & 2 & 0 & 0 \\
\hline 30 & 30 & 90 & 50 & -2 & 0 & 0 \\
\hline
\end{tabular}

Table 2: Observed values of dependent variables for different runs of optimization experiments. 
data using a commercial statistical package (Design expert, trial version 6.0.10) for the generation of response surface plots and optimization process variables. The experiments were conducted according to Central Composite Rotatable Design (CCRD) [9]. Five levels of each variable were chosen for study, including 2 centre points and 2 axial points. A factorial study was used to study the effects of temperature $\left(\mathrm{X}_{1}\right)$, processing time $\left(\mathrm{X}_{2}\right)$ sugar concentration $\left(\mathrm{X}_{3}\right)$ of the pine apple cubes.

$$
\begin{aligned}
& X 1=\frac{\text { temperature }-40}{5} \\
& X 2=\frac{\text { immersiontime }-90}{30} \\
& X 3=\frac{\text { sugarconcentration }-50}{5}
\end{aligned}
$$

In order to follow adequately the osmotic dehydration kinetics, individual analysis for each sample were carried out and from these weight reductions (WR), solid gain (SG) and water loss (WL) data were obtained according to the expressions.

$$
\begin{aligned}
& W R=\left(\frac{M o-M}{M o}\right) \\
& W L=\{(W o-W t)+(S t-S o)\} \times 100 / W o \\
& S G=\left(\frac{S t-S o}{W o}\right) \times 100
\end{aligned}
$$

where Mo-initial mass of sample (g), M-mass of sample after dehydration $(\mathrm{g}), \mathrm{W}$ is the initial weight taken for osmotic dehydration at any time $(\mathrm{g}), \mathrm{S}_{\mathrm{o}}$ is the initial dry matter $(\mathrm{g})$, St is the dry matter of after osmotic dehydration for any time ( $\mathrm{g})$.

\section{Results and Discussion}

\section{Fitting models}

Experiments were performed according to the CCD experimental design given in Table 2 in order to search for the optimum combinations of parameters for the osmotic dehydration of pineapple cubes. The Model F-Value of $6.27,11.35$ \& 9.91 for WL, WR \& SG respectively implies the model is significant. There is only a $0.03 \%$ chance that a "Model F-Value" this large could occur due to noise. Values of "Prob $>F$ " less than 0.0500 indicates model terms are significant. In this case $\mathrm{X}_{2}, \mathrm{X}_{3}, \mathrm{X}_{2}^{2}$ are significant model terms. Values greater than 0.1000 indicate the model terms are not significant. The "Lack of Fit F-Value" of $5.78,17.32$ \& 1.52 for WL, WR \& SG respectively implies the lack of fit is significant. There is only a $0.36 \%$ chance that a "Lack of Fit F-Value" this large could occur due to noise. The goodness of fit of the model is checked by determination coefficient $\left(\mathrm{R}^{2}\right)$. The coefficient of determination was calculated to be $0.7382,0.7627 \& 0.8169$ for WL, WR \& SG respetively. The $\mathrm{R}^{2}$ value is always between 0 and 1 , and a value $>0.75$ indicates aptness of the model. For the good statistical model, $\mathrm{R}^{2}$ value should be close to 1 . The adjusted $\mathrm{R}^{2}$ value corrects the $\mathrm{R}^{2}$ value for the sample size and for the no. of terms in the model and the sample size is not very large, the adjusted $\mathrm{R}^{2}$ may be noticeably smaller than the $\mathrm{R}^{2}$. The adjusted $\mathrm{R}^{2}$ value is $0.6204,0.7627 \& 0.7345$ for WL, WR \& SG respectively. The predicted $\mathrm{R}^{2}$ is WL 0.4315 , WR 0.6312 \& SG-0.6081 are in reasonable agreement with the adjusted $\mathrm{R}^{2}$. Values of CV is also as low as WL 9.81\%, WR-18.54\% \& SG $18.57 \%$ indicate that the deviations between experimental \& predicted values are low. Adequate measures the signal to noise ratio. A ratio greater than 4 is desirable. In this work the ratio is found to be $8.447,10.088 \& 9.014$ for WL, WR \& SG respectively indicates an adequate signal.
The experimental results are analyzed through RSM to obtain in empirical model for the best response. The mathematical expression of relationship to the response with variables are shown below.

$$
\begin{aligned}
& Y_{1}=30.83+1.30 X_{1}+2.83 X_{2}+2.08 X_{3}-0.27 X_{1}{ }^{2}-1.76 X_{2}^{2}-0.021 \\
& X_{3}^{2}+0.9 X_{1} X_{2}-0.19 X_{1} X_{3}-0.86 X_{2} X_{3} \\
& Y_{2}=18.49+1.84 X_{1}+4.99 X_{2}+1.34 X_{3}-1.95 X_{1}^{2}-0.56 X_{2}^{2}+0.13 \\
& X_{3}^{2}-1.11 X_{1} X_{2}-0.062 X_{1} X_{3}+0.9 X_{2} X_{3} \\
& Y_{3}=14.60+3.30 X_{1}+1.24 X_{2}+2.23 X_{3}+0.1 X_{1}{ }^{2}-1.27 X_{2}^{2}+0.5 X_{3}^{2} \\
& +0.93 X_{1} X_{2}+1.3 X_{1} X_{3}-1.4 X_{2} X_{3}
\end{aligned}
$$

where $\mathrm{Y}_{1}, \mathrm{Y}_{2} \& \mathrm{Y}_{3}$ are water loss (\%), weight reduction (\%) \& solid gain (\%) respectively, and $\mathrm{X}_{1}, \mathrm{X}_{2} \& \mathrm{X}_{3}$ are the coded values of the test variables, temperature $\left({ }^{\circ} \mathrm{C}\right)$, processing time $(\mathrm{min})$ \& sugar concentration $\left({ }^{\circ} \mathrm{B}\right)$.

The standard scores were fitted to a quadratic polynomial regression model for predicting individual $Y$ responses by employing at least square technique (Wanasaundara and Shahidi, 1966). The second order polynomial equation was fitted to the experimental data of each dependent variable as given. The model proposed to each response of $\mathrm{Y}$ was

$$
Y=\beta o+\sum_{i=1}^{3} \beta i i X i+\sum_{i=1}^{3} \beta i i \mathrm{X}^{2}+\sum_{\mathrm{i}<j=1} \beta i j X i X j
$$

where $ß 0,{ }_{3} \mathrm{i}, \mathrm{Bij}_{\mathrm{j}}$ are intercepts, quadratic regression coefficient terms. $\mathrm{Xi}$ and $\mathrm{Xj}$ are independent variables. The model permitted evaluation of quadratic terms of the independent variables on the dependent variable. The response surface and contour plot were generated for different interactions of any two independent variables, where holding the value of third variables as constant at central level. The optimization of the process was aimed at finding the optimum values of independent variables.

The result for multiple linear regressions conducted for the second order response surface model are given in Table 3-5. The significance of each coefficient was determined by Student's t-value and smaller the p-value, the more significant is the corresponding coefficient. Values of "Prob $>$ F" less than 0.0500 indicate model terms are significant. In this case, $\mathrm{X}_{1}, \mathrm{X}_{2}, \mathrm{X}_{3}, \mathrm{X}_{1} \mathrm{X}_{2}$ and $\mathrm{X}_{1} \mathrm{X}_{3}$ for WL $\mathrm{X}_{1}, \mathrm{X}_{2}, \mathrm{X}_{3}, \mathrm{X}_{3}^{2}$ and $\mathrm{X}_{2} \mathrm{X}_{3}$ for $W R$ and $X_{1}, X_{2}, X_{1}, X_{1}^{2}, X_{3}^{2}, X_{1} X_{2}$ and $X_{1} X_{3}$ for SG are significant model terms. Values greater than 0.10 indicate the model terms are not significant. This implies that the linear are more significant than the other factors.

\section{Response surfaces and contour plots}

Response surface plots as a function of two factors at a time, maintaining all other factors at fixed levels are more helpful in understanding both the main and the interaction effects of these two factors. These plots can be easily obtained by calculating from the model, the values taken by one factor where the second varies with constraint of a given $\mathrm{Y}$ value. The response surface curves were plotted to understand the interaction of the variables and to determine the optimum level of each variable for maximum response. The response surface curves shown in Figure (1-9). The nature of the response surface curves shows the interaction between the variables. The elliptical shape of the curve indicates good interaction of the two variables and circular shape indicates no intercation between the variables. From fiqures it was observed that the elliptical nature of the contour in 3D-response surface graphs depict the mutual interaction between every two variables. There was a relative significant interaction between every two 
Citation: Sridevi M, Genitha Er TR (2012) Optimization of Osmotic Dehydration Process of Pineapple by Response Surface Methodology. J Food Process Technol 3:173. doi:10.4172/2157-7110.1000173

Page 4 of 7

\begin{tabular}{|c|c|c|c|c|c|c|c|c|c|}
\hline \multirow[b]{2}{*}{ Design } & \multicolumn{3}{|c|}{ Coded values } & \multicolumn{3}{|c|}{ Experimental \% } & \multicolumn{3}{|c|}{ Predicted \% } \\
\hline & $x_{1}$ & $x_{2}$ & $x_{3}$ & WL & WR & SG & WL & WR & SG \\
\hline 1 & 0 & 0 & 0 & 21.91 & 8.57 & 7.15 & 23.07 & 7.67 & 8.00 \\
\hline 2 & 1 & -1 & -1 & 20.88 & 8.07 & 8.81 & 23.07 & 7.67 & 8.00 \\
\hline 3 & -1 & -1 & 1 & 24.01 & 11.52 & 12.48 & 22.95 & 13.69 & 10.13 \\
\hline 4 & 0 & 0 & 0 & 23.55 & 10.71 & 12.84 & 22.95 & 13.69 & 10.13 \\
\hline 5 & 1 & -1 & -1 & 26.93 & 16.16 & 11.78 & 28.64 & 18.06 & 11.42 \\
\hline 6 & 0 & 0 & 2 & 27.97 & 16.86 & 11.11 & 28.64 & 18.06 & 11.42 \\
\hline 7 & 1 & -1 & 1 & 31.44 & 17.92 & 13.51 & 32.12 & 19.64 & 17.28 \\
\hline 8 & -1 & 1 & -1 & 26.44 & 14.15 & 20.29 & 32.12 & 19.64 & 17.28 \\
\hline 9 & 2 & 0 & 0 & 29.91 & 10.17 & 13.73 & 28.56 & 8.68 & 12.65 \\
\hline 10 & 1 & 1 & -1 & 28.91 & 10.97 & 13.48 & 28.56 & 8.68 & 12.65 \\
\hline 11 & 0 & 0 & -2 & 26.44 & 14.15 & 20.29 & 29.22 & 14.45 & 19.99 \\
\hline 12 & -2 & 0 & 0 & 29.72 & 14.41 & 20.80 & 29.22 & 14.45 & 19.99 \\
\hline 13 & 0 & 2 & 0 & 28.66 & 23.37 & 9.29 & 30.70 & 22.68 & 10.46 \\
\hline 14 & -1 & 1 & 1 & 26.43 & 23.70 & 7.73 & 30.70 & 22.68 & 10.46 \\
\hline 15 & 0 & 0 & 2 & 34.15 & 23.30 & 22.81 & 34.96 & 24.01 & 21.52 \\
\hline 16 & -1 & -1 & -1 & 34.46 & 19.99 & 21.42 & 34.96 & 24.01 & 21.52 \\
\hline 17 & 1 & 1 & 1 & 29.24 & 7.91 & 10.32 & 28.32 & 9.90 & 9.33 \\
\hline 18 & -1 & 1 & -1 & 31.31 & 8.05 & 10.09 & 28.31 & 9.90 & 9.33 \\
\hline 19 & 0 & 0 & -2 & 36.56 & 20.83 & 20.82 & 31.80 & 16.08 & 20.43 \\
\hline 20 & 1 & 1 & -1 & 29.72 & 20.04 & 16.67 & 31.80 & 16.08 & 20.43 \\
\hline 21 & 0 & -2 & 0 & 20.89 & 7.91 & 5.99 & 21.10 & 8.52 & 8.93 \\
\hline 22 & -1 & -1 & -1 & 20.42 & 7.71 & 7.66 & 21.10 & 8.52 & 8.93 \\
\hline 23 & 0 & -2 & 0 & 33.17 & 28.26 & 15.91 & 30.61 & 25.30 & 13.10 \\
\hline 24 & -1 & -1 & 1 & 35.52 & 28.63 & 12.89 & 30.61 & 25.30 & 13.10 \\
\hline 25 & -1 & 1 & 1 & 30.53 & 20.74 & 13.80 & 27.26 & 16.59 & 12.27 \\
\hline 26 & 0 & 2 & 0 & 27.65 & 19.21 & 8.74 & 27.26 & 16.59 & 12.27 \\
\hline 27 & 1 & -1 & 1 & 34.94 & 19.20 & 15.75 & 34.27 & 21.11 & 19.76 \\
\hline 28 & 1 & 1 & 1 & 36.23 & 21.12 & 24.15 & 34.27 & 21.11 & 19.76 \\
\hline 29 & 2 & 0 & 0 & 30.75 & 15.85 & 14.89 & 30.83 & 18.49 & 14.60 \\
\hline 30 & -2 & 0 & 0 & 29.78 & 20.30 & 14.58 & 30.83 & 18.49 & 14.60 \\
\hline
\end{tabular}

Table 3: Experimental condition and observed respond values of CCD.

\begin{tabular}{|c|c|c|c|c|c|c|}
\hline Source & $\begin{array}{l}\text { Coefficient of } \\
\text { estimation }\end{array}$ & Sum of squares & DF & Mean squares & f-value & $\begin{array}{l}p \text {-value } \\
\text { prob }>f\end{array}$ \\
\hline Model & 30.83 & 455.26 & 9 & 50.58 & 6.27 & $0.0003^{*}$ \\
\hline$X_{1}$ & 1.03 & 29.19 & 1 & 29.19 & 3.62 & 0.0717 \\
\hline $\mathrm{X}_{2}$ & 2.83 & 218.24 & 1 & 218.24 & 27.04 & $<0.0001$ \\
\hline $\mathrm{X}_{3}$ & 2.08 & 118.54 & 1 & 118.54 & 14.69 & 0.0010 \\
\hline $\mathrm{X}_{1}{ }^{2}$ & -0.27 & 0.90 & 1 & 0.90 & 0.11 & 0.7422 \\
\hline $\mathrm{X}_{1}^{2}$ & -1.76 & 37.42 & 1 & 37.42 & 4.64 & 0.0437 \\
\hline $\mathrm{X}_{1}^{2}$ & -0.021 & 5.559E-003 & 1 & $5.559 \mathrm{E}-003$ & 6.886E-004 & 0.9793 \\
\hline $\mathrm{X}_{1} \mathrm{X}_{2}$ & 0.90 & 12.96 & 1 & 12.96 & 1.61 & 0.2197 \\
\hline $\mathrm{X}_{1} \mathrm{X}_{3}$ & 0.19 & 0.60 & 1 & 0.60 & 0.075 & 0.7875 \\
\hline$X_{2} X_{3}$ & -0.86 & 11.75 & 1 & 11.75 & 1.46 & 0.2418 \\
\hline Residual & & 161.44 & 20 & 8.07 & & \\
\hline Lack of Fit & & 106.27 & 5 & 21.25 & 5.78 & $0.0036^{*}$ \\
\hline Pure error & & 55.17 & 15 & 3.68 & & \\
\hline Corrected Total & & 616.69 & 29 & & & \\
\hline Std. Dev & & 2.84 & & & & \\
\hline $\mathrm{R}^{2}$ & & 0.7382 & & & & \\
\hline Adj $R^{2}$ & & 0.6204 & & & & \\
\hline Pred. $\mathrm{R}^{2}$ & & 0.4315 & & & & \\
\hline Adeq. Precision & & 8.447 & & & & \\
\hline $\mathrm{CV} \%$ & & 9.81 & & & & \\
\hline
\end{tabular}

DF - Degrees of Freedom, *- $5 \%$ level of significant

Table 4: ANOVA for response surface quadratic model for osmotic dehydration of pineapple- water loss. 
Citation: Sridevi M, Genitha Er TR (2012) Optimization of Osmotic Dehydration Process of Pineapple by Response Surface Methodology. J Food Process Technol 3:173. doi:10.4172/2157-7110.1000173

Page 5 of 7

\begin{tabular}{|c|c|c|c|c|c|c|}
\hline Source & $\begin{array}{l}\text { Coefficient of } \\
\text { estimation }\end{array}$ & Sum of squares & DF & Mean squares & f-value & $\begin{array}{l}p \text {-value } \\
\text { prob }>f\end{array}$ \\
\hline Model & 18.49 & 935.87 & 9 & 103.99 & 11.35 & $<0.0001$ \\
\hline $\mathrm{X}_{1}$ & 1.84 & 92.16 & 1 & 92.16 & 10.06 & 0.0048 \\
\hline$x_{2}$ & 4.99 & 680.11 & 1 & 680.11 & 74.26 & $<0.0002$ \\
\hline $\mathrm{X}_{3}$ & 1.34 & 49.34 & 1 & 49.34 & 5.39 & 0.0310 \\
\hline$X_{1}^{2}$ & -1.95 & 45.85 & 1 & 48.85 & 5.01 & 0.0368 \\
\hline$X_{1}^{2}$ & -0.56 & 3.80 & 1 & 3.80 & 0.42 & 0.5266 \\
\hline $\mathrm{X}_{1}^{2}$ & 0.13 & 0.19 & 1 & 0.19 & 0.021 & 0.8869 \\
\hline $\mathrm{x}_{1} \mathrm{x}_{2}$ & -1.11 & 19.68 & 1 & 19.68 & 2.15 & 0.1583 \\
\hline $\mathrm{X}_{1} \mathrm{X}_{3}$ & -0.062 & 0.062 & 1 & 0.062 & $6.811 \mathrm{E}-003$ & 0.9350 \\
\hline $\mathrm{X}_{2} \mathrm{X}_{3}$ & 0.90 & 13.06 & 1 & 13.06 & 1.43 & 0.2464 \\
\hline Residual & & 183.17 & 20 & 9.16 & & \\
\hline Lack of Fit & & 156.13 & 5 & 31.23 & 17.32 & $<0.0001$ \\
\hline Pure error & & 27.04 & 15 & 1.80 & & \\
\hline Corrected Total & & 1119.04 & 29 & & & \\
\hline Std. Dev & & 3.03 & & & & \\
\hline$R^{2}$ & & 0.8363 & & & & \\
\hline Adj $R^{2}$ & & 0.7627 & & & & \\
\hline Pred. $\mathrm{R}^{2}$ & & 0.6312 & & & & \\
\hline Adeq. Precision & & 10.088 & & & & \\
\hline CV\% & & 18.54 & & & & \\
\hline
\end{tabular}

DF - Degrees of Freedom *- 5\% level of significant

Table 5: ANOVA for response surface quadratic model for osmotic dehydration of pineapple- Weight Reduction (WR).

variables, and there was a maximum predicted yield indicated by the surface confined in the smallest ellipse in the contour diagram.

Water loss: From the Table 3 the magnitude of $\mathrm{P}$ and $\mathrm{F}$ values indicates the maximum positive contribution of all the three variables namely temperature, processing time \& sugar concentration on the water loss during osmotic dehydration. It implies increased water loss with increase in all the process variables. Further, the interaction $\mathrm{X}_{1}-\mathrm{X}_{2}$ and $\mathrm{X}_{1}-\mathrm{X}_{3}$ has positive effect and $\mathrm{X}_{2}-\mathrm{X}_{3}$ has negative effect on water loss. This is due to rise on fruit membrane permeability caused by higher temperatures promotes swelling \& plasticization of cell membrane, favouring mass transfer $[10,11]$. Higher temperatures promote faster water loss through swelling and plasticizing of cell membranes as well as the better water transfer characteristics on the product surface due to lower viscosity of the osmotic medium $[12,13]$.

Weight reduction: From Table 4 the magnitude of $\mathrm{P}$ and

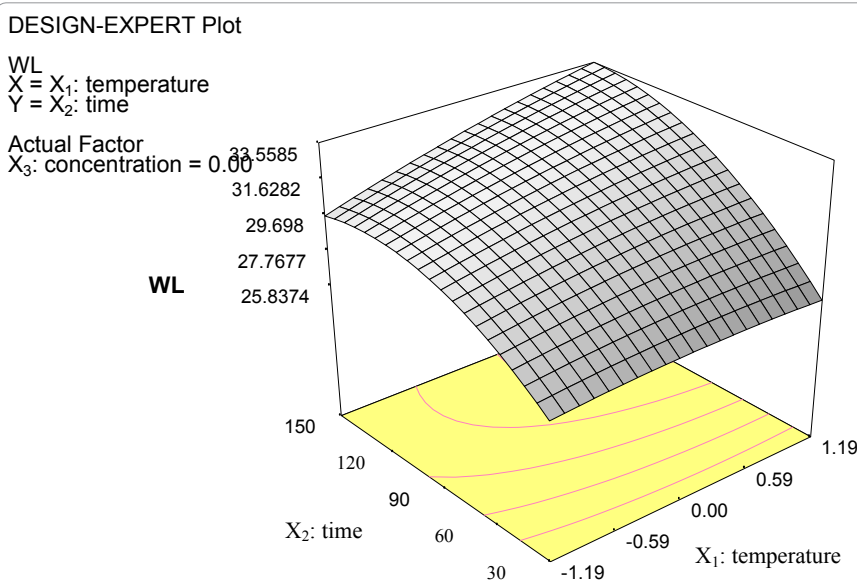

Figure 1: $3 \mathrm{D}$ plot of combined effect of temperature and processing time on water loss.

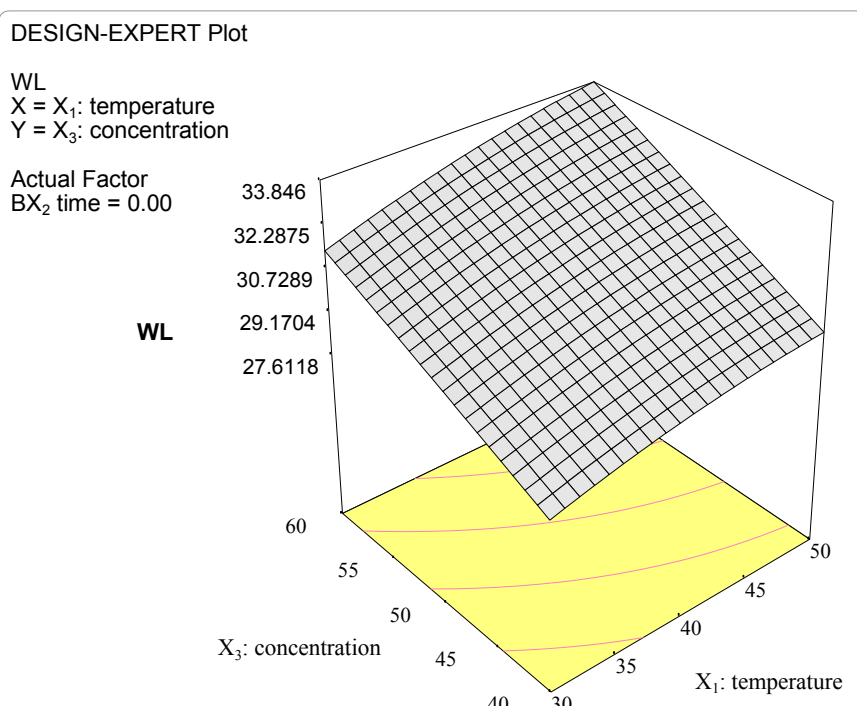

Figure 2: $3 \mathrm{D}$ plot of combined effect of temperature and sugar concentration on water loss.

F-values indicates the maximum positive contribution of all the three variables, temperature, processing time \& sugar concentration on the weight reduction during osmotic dehydration. It implies weight reduction increased with increase in all the three variables. Further the interaction of $\mathrm{X}_{1}-\mathrm{X}_{2} \& \mathrm{X}_{1}-\mathrm{X}_{3}$ has negative effect and $\mathrm{X}_{2}-\mathrm{X}_{3}$ has positive effect on weight reduction. Weight reduction increased with increase in immersion time. Similar results were found by Jokie et al. [14]. He investigated the influence of time on the osmotic dehydration of sugar beet; results showed that weight reduction was linearly effected by immersion time.

Solid gain: From the Table 6 the magnitude of $\mathrm{P}$ and $\mathrm{F}$ values indicate the maximum positive contribution of all the three variables 


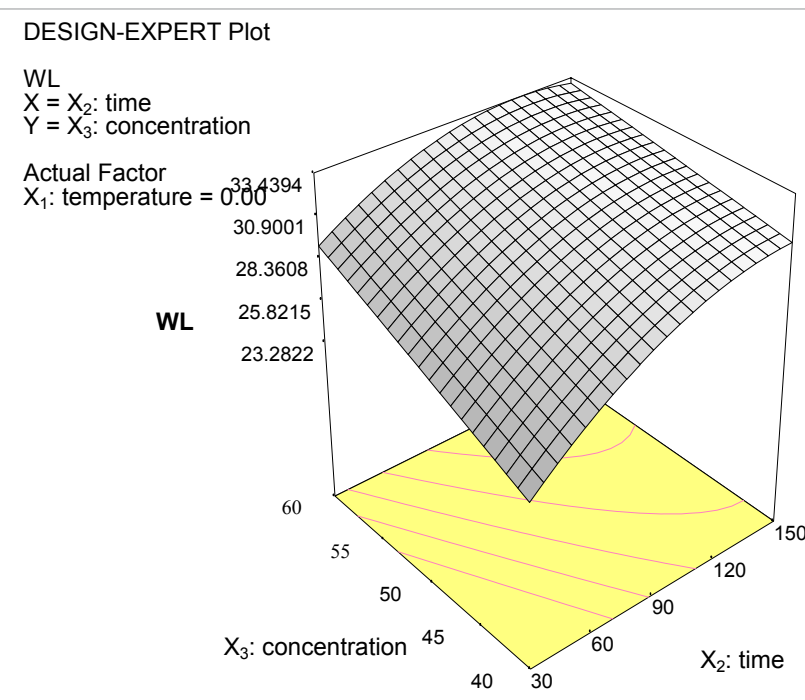

Figure 3: $3 \mathrm{~d}$ plot of combined effect of sugar concentration and processing time on water loss.

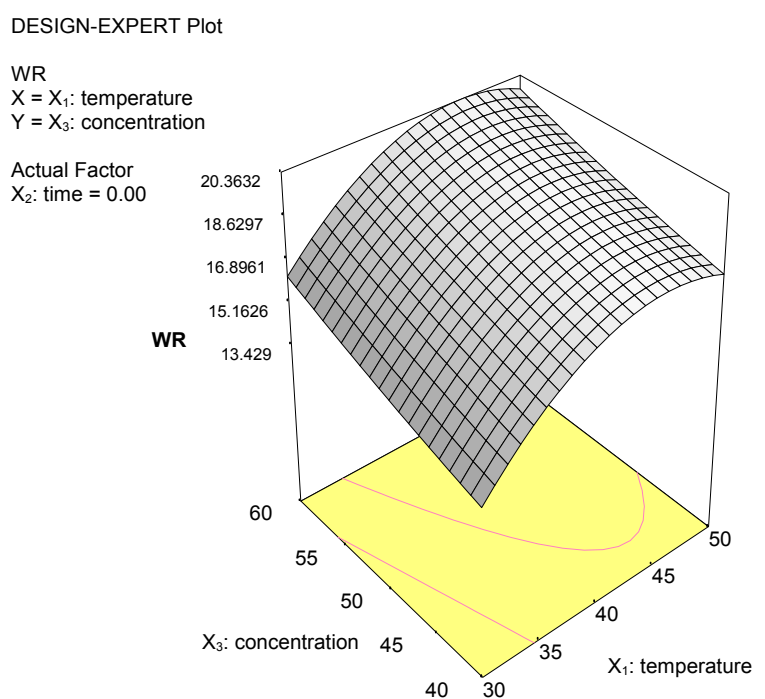

Figure 4: 3D plot of combined effect of temperature and sugar concentration on water reduction.

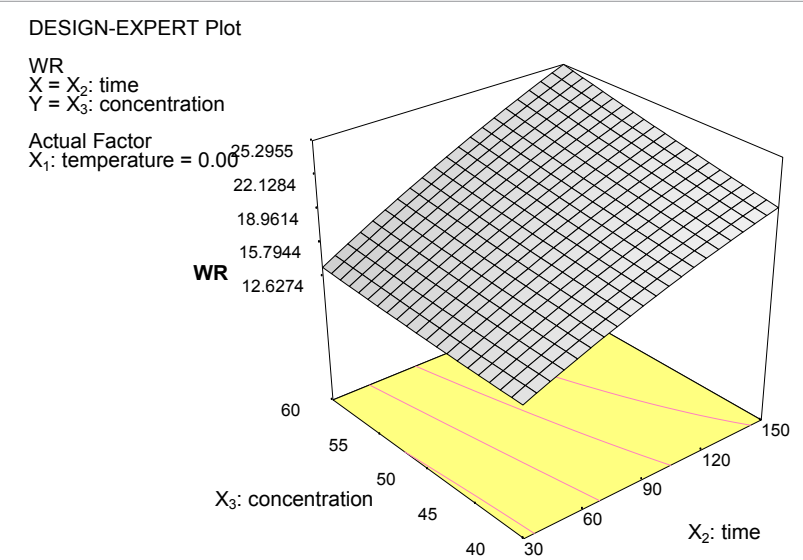

Figure 5: 3D plot of combined effect of sugar concentration and processing time on water reduction.

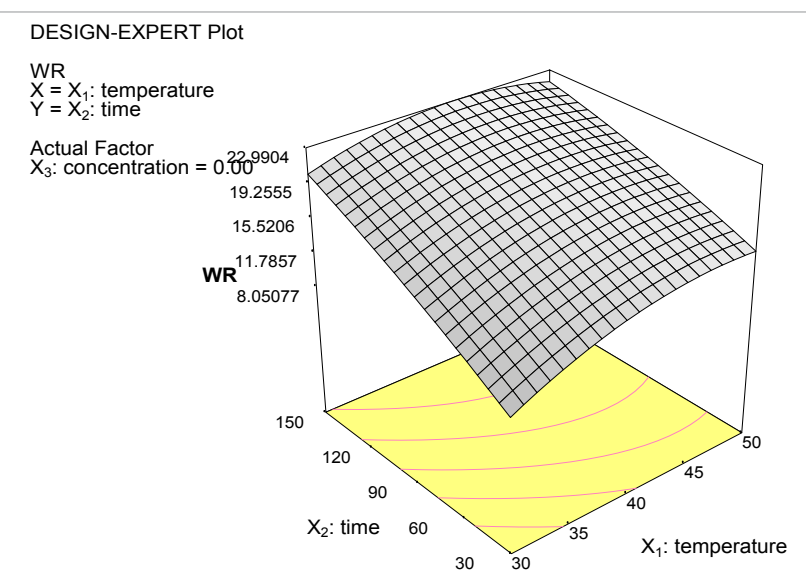

Figure 6: 3D plot of combined effect of temperature and processing time on water reduction.

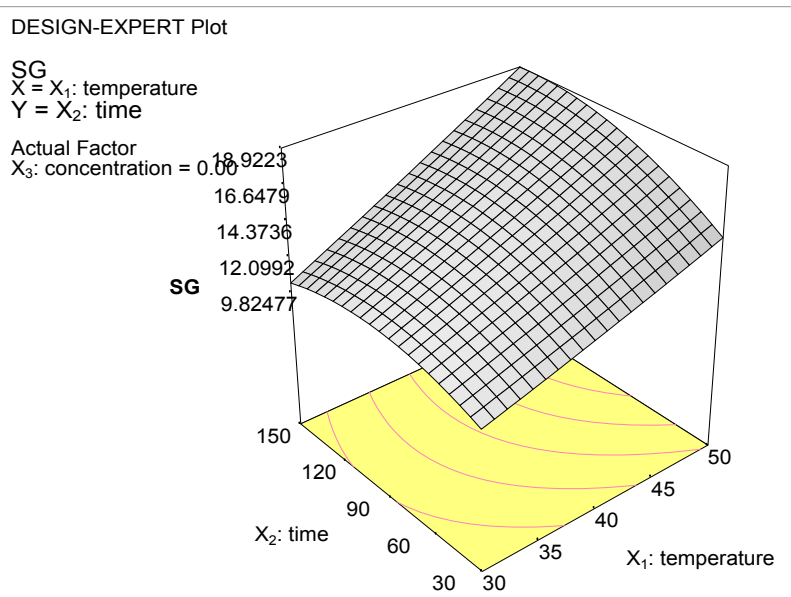

Figure 7: 3D plot of combined effect of temperature and processing time on solid gain.

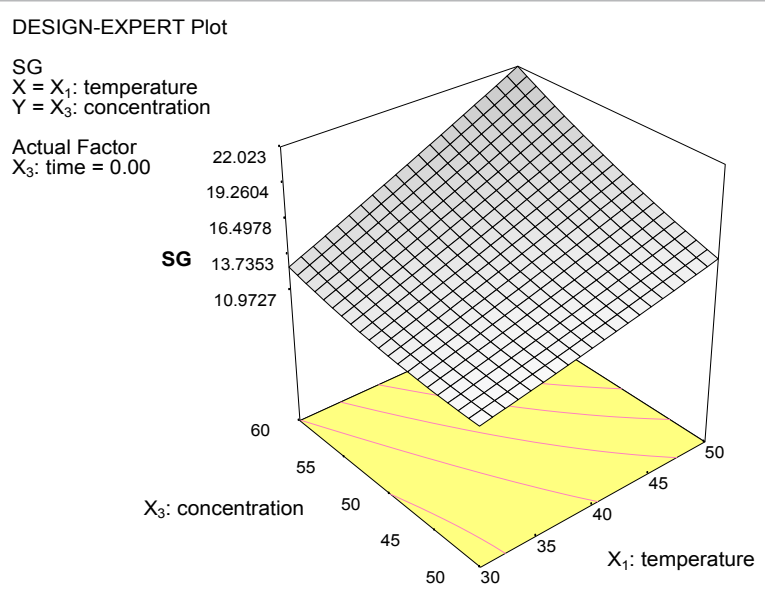

Figure 8: $3 \mathrm{D}$ plot of combined effect of temperature and sugar concentration on solid gain.

namely temperature, processing time \& sugar concentration on the solid gain. Further the interaction $\mathrm{X}_{1}-\mathrm{X}_{2}$ and $\mathrm{X}_{1}-\mathrm{X}_{3}$ has positive effect and $\mathrm{X}_{2}-\mathrm{X}_{3}$ has negative effect on solid gain during osmotic dehydration. The experimental values for water loss \& solid gain under different 


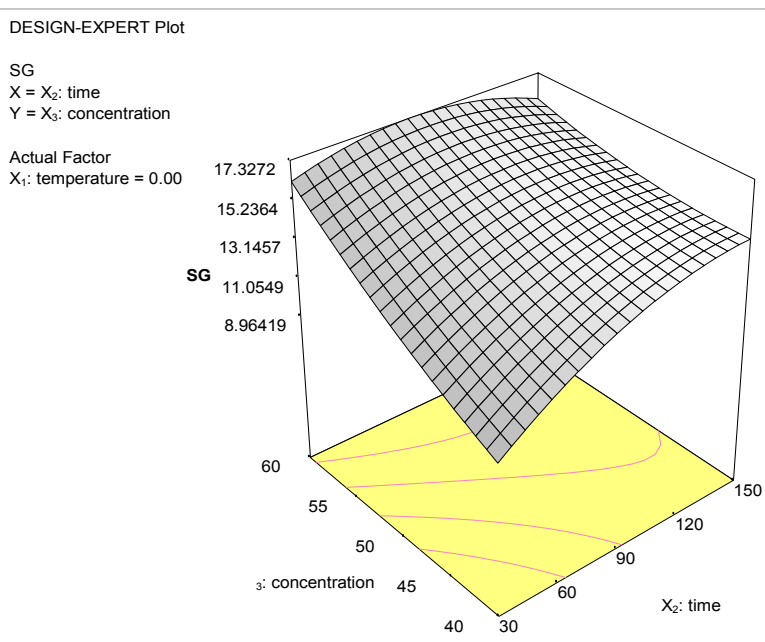

Figure 9: 3D plot of combined effect of sugar concentration and processing time on solid gain.

\begin{tabular}{|c|c|c|c|c|c|c|}
\hline Source & $\begin{array}{l}\text { Coefficient of } \\
\text { estimation }\end{array}$ & $\begin{array}{l}\text { Sum of } \\
\text { squares }\end{array}$ & DF & $\begin{array}{l}\text { Mean } \\
\text { squares }\end{array}$ & f-value & $\begin{array}{l}p \text {-value } \\
\text { prob }>f\end{array}$ \\
\hline Model & 14.60 & 602.54 & 9 & 66.95 & 9.91 & $<0.0001^{*}$ \\
\hline$x_{1}$ & 3.3 & 297.15 & 1 & 297.15 & 44.00 & $<0.0001$ \\
\hline $\mathrm{X}_{2}$ & 1.24 & 41.91 & 1 & 41.91 & 6.21 & 0.0216 \\
\hline $\mathrm{X}_{3}$ & 2.23 & 135.27 & 1 & 135.27 & 20.03 & 0.0002 \\
\hline$X_{1}{ }^{2}$ & 0.10 & 0.12 & 1 & 0.12 & 0.018 & 0.8947 \\
\hline$X_{1}{ }^{2}$ & -1.27 & 19.40 & 1 & 19.40 & 2.87 & 0.1056 \\
\hline $\mathrm{X}_{1}^{2}$ & 0.50 & 3.04 & 1 & 3.04 & 0.45 & 0.5098 \\
\hline $\mathrm{x}_{1} \mathrm{X}_{2}$ & 0.93 & 13.87 & 1 & 13.87 & 2.05 & 0.1673 \\
\hline $\mathrm{X}_{1} \mathrm{X}_{3}$ & 1.30 & 27.09 & 1 & 27.09 & 4.01 & 0.0589 \\
\hline $\mathrm{X}_{2} \mathrm{X}_{3}$ & -1.40 & 31.53 & 1 & 31.53 & 4.67 & 0.0430 \\
\hline Residual & & 135.06 & 20 & 6.75 & & \\
\hline Lack of Fit & & 43.35 & 5 & 9.07 & 1.52 & $0.2433 \mathrm{NS}$ \\
\hline Pure error & & 89.71 & 15 & 5.98 & & \\
\hline Corrected Total & & 737.60 & 29 & & & \\
\hline Std. Dev & & 2.60 & & & & \\
\hline $\mathrm{R}^{2}$ & & 0.8169 & & & & \\
\hline Adj $R^{2}$ & & 0.7345 & & & & \\
\hline Pred. $\mathrm{R}^{2}$ & & 0.6081 & & & & \\
\hline Adeq. Precision & & 9.014 & & & & \\
\hline CV\% & & 18.57 & & & & \\
\hline
\end{tabular}

DF - Degrees of Freedom, NS-non significant, * $5 \%$ level of significant

Table 6: ANOVA for response surface quadratic model for osmotic dehydration of pineapple- Solid Gain (SG).

treatment conditions showed that water removal was always higher than the osmotic agent uptake, in agreement with the results of other workers [10].

\section{Optimum condition for osmotic dehydration}

Optimum conditions for osmotic dehydration of pineapple was determined to obtain maximum water loss and weight reduction and minimum solid gain. Second order polynomial models obtained in this study were utilised for each response to determine the specified optimum conditions. The sequential quadratic programming in Design-Expert $\mathrm{D} \times 6$ 6.0.10 is used to solve the second degree polynomial regression equation $7,8,9$. The optimum values obtained by substituting the respective coded values of variables are $38.2^{\circ} \mathrm{C}, 125.7 \mathrm{~min}, 44.05^{\circ} \mathrm{B}$. At this point, water loss, weight reduction and solid gain was calculated as 30.0921 (g/100g initial sample), 20.3772 ( $\mathrm{g} / 100 \mathrm{~g}$ initial sample) \& 13.3634 (g/100g initial sample).

\section{Conclusion}

It can be concluded from this study that solution temperature and sugar concentration were the most pronounced factors affecting solid gain and water loss of pineapple cubes during osmotic dehydration followed by immersion time. Results obtained evident that osmotic dehydration using sucrose solution was able to improve the quality of hot air drying of pineapple cubes in term of the colour, texture, aroma, appearance as well as overall acceptability. The regression equations obtained in this study were successfully used to predict optimum conditions for the maximum water loss \& weight reduction and minimum solid gain and physical properties of dried pineapple cubes.

\section{References}

1. Raoult-Wack AL (1994) Recent advances in osmotic dehydration. Trends Food Sci Technol 5: 255-260.

2. Panagiotou NM, Karathanos VT, Maroulis ZB (1998) Mass transfer modelling of the osmotic dehydration of some fruits. International Journal of Food Science and Technology 33: 267-284.

3. Rahman MS, Perera C (1999) Osmotic dehydration: a pretreatment for fruit and vegetables to improve quality and process efficiency. The Food Technologis 25: $144-147$

4. Chiralt A, Martinez-Navarrete NM, Martinez-Monzo J, Talens P, Moraga G, et al. (2001) Changes in mechanical properties throughout osmotic processes: Cryoprotectant effect. J Food Eng 49: 129-135.

5. Talens P, Martinez-Navarrete N, Fito P, Chiralt A (2002) Changes in optica and mechanical properties during osmodehydrofreezing of kiwi fruit. Innovative Food Science and Emerging Technologies 3: 191-199.

6. Simal S, Deya E, Frau M, Rossello C (1997) Simple modelling of air drying curves of fresh and osmotically pre-dehydrated apple cubes. J Food Eng 33 139-150.

7. Del Valle JM, Cuadros TRM, Aguilera JM (1998) Glass transition and shrinkage during drying and storage of osmosed apple pieces. Food Research International 31: 191-204.

8. Pokharkar S, Prasad S, Das H (1997) A model of osmotic concentration of banana slices. Food Res Int 34: 230-232.

9. Khuri Al, Cornell JA (1997) Secondary Design considerations for Minimum Bias Estimation. Commun Stat Theory Methods 6: 631-647.

10. Lazarides HN, Mavroudis NE (1995) Freeze/Thaw effects on mass transfer rates during osmotic dehydration. J Food Sci 60: 826-828.

11. Uddin MB, Ainsworth P, Ibanoglu S (2004) Evaluation of mass exchange during osmotic dehydration of carrots using response surface methodology. $\mathrm{J}$ Food Eng 65: 473-477.

12. Contreras JE, Smyrl TG (1981) An Evaluation of osmotic concentration of apple rings using corn syrup solids solutions. Canadian Institute of Food Science and Technology 14: (pp. 310-314).

13. Lazarides HN, Gekas V, Mavroudis N (1997) Apparent mass diffusivities in fruit and vegetable tissues undergoing osmotic processing. J Food Eng 31 315-324.

14. Jokie A, Gyura J, Levic L, Zavargo Z (2007) Osmotic dehydration of sugar beet in combined aqueous solution of sucrose and sodium chloride. J Food Eng 78: 47-51. 